\title{
INFERÊNCIAS SOBRE A INCERTEZA NA FORMAÇÃO MIDIATIZADA BRASILEIRA: O CASO DA CRÍTICA NO OBSERVATÓRIO DE IMPRENSA
}

\author{
INFERENCES ON THE UNCERTAINTY IN THE BRAZILIAN MEDIATIZED \\ SHAPING: THE CASE OF THE REVIEW AT OBSERVATÓRIO DE IMPRENSA
}

\author{
LAS INFERENCIAS SOBRE LA INCERTIDUMBRE EN LA FORMACIÓN \\ MEDIATIZADA BRASIL: EL CASO DE LA CRÍTICA EN EL OBSERVATÓRIO \\ DE IMPRENSA
}

\author{
Jairo G Ferreira \\ Doutor, Universidade do Vale do Rio dos Sinos \\ jferreira@unisinos.br \\ Adriana Domingues Adriana \\ Universidade do Vale do Rio dos Sinos \\ adrigarciasm@gmail.com
}

\section{Resumo}

Neste artigo, nosso objetivo é relacionar as proposições sobre a incerteza como inerente aos processos midiatizados no Brasil e a análise de interações em curso em dispositivos midiáticos estruturados a partir das tecnologias chamadas de Web 2.0. O contexto empírico do caso aqui construído é o Observatório de Imprensa. As questões de investigação são: em que medida as transformações tecnológicas do OI produzem instabilidade no dispositivo estrategicamente desenhado pela instituição (no caso, de crítica da mídia)? Procuramos responder a essa questão observando as transformações nas interações semio-discursivas antes e depois das transformações da plataforma do OI.

Palavras-chave: Midiatização. Incerteza. Fragmentação.

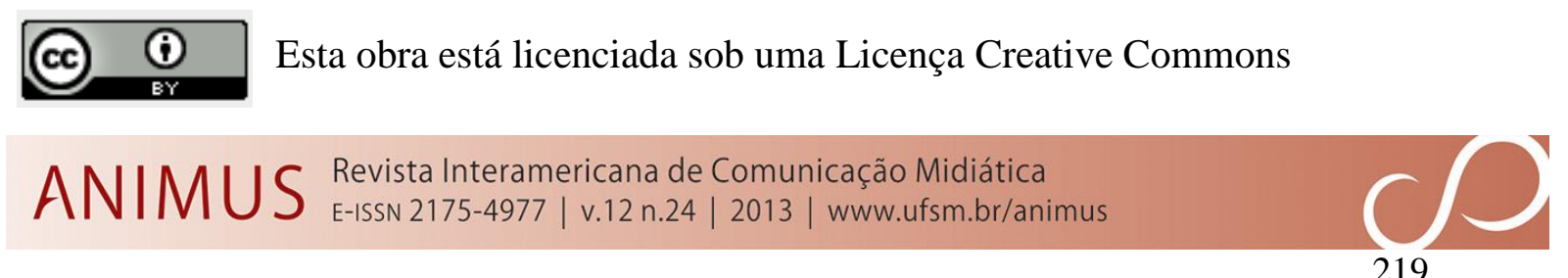




\begin{abstract}
In this paper, our goal is to connect the propositions on the uncertainty as inherent to mediatized processes in Brazil and the analysis of interactions in course in structured mediatic dispositifs from technologies so-called Web $2.0 \mathrm{on}$. The empirical context of the constructed case in point here is the Observatório de Imprensa. The questions of investigation are: in what extent the technological transformations of OI produce instability in the dispositif strategically designed by the institution (in case, of reviews of media) ? We try to answer this question by watching transformations in the interactions semio-discursive ones before and after of transformations of OI platform.
\end{abstract}

Key-words: Mediatization. Uncertainty. Fragmentation.

\title{
Resumen
}

En este artículo, nuestro objetivo es relacionar las proposiciones sobre la incertidumbre inherente a procesos mediatizados em formaciones tipicas del Brasil, con el análisis de las interacciones en curso en los dispositivos mediaticos estructurados con las nuevas tecnologías de la llamada Web 2.0. El contexto empírico del caso aquí se construyó el Observatório de Imprensa. Las preguntas de investigación son: ¿hasta qué punto las transformaciones tecnológicas producen inestabilidad en el dispositivo estratégico diseñado por la institución (en el caso, la critica a los medios de comunicacion)? Tratamos de responder a esta pregunta mediante la observación de los cambios en las interacciones semio-discursivas antes y después de transformaciones de plataforma del OI.

Palabras clave: Mediatización. Incertidumbre. Fragmentación.

\section{INTRODUÇÃO}

Este artigo desenvolve uma reflexão sobre a incerteza considerando dois níveis: primeiro, o macro social, a partir do conceito de formação midiatizada brasileira, na qual as interações e usos tem valor maior do que as práticas sociais na esfera da cultura; segundo, o micro-social, buscando inferências as interações no Observatório de Imprensa, um dispositivo de crítica da mídia. Nosso objetivo é relacionar as proposições sobre a incerteza como inerente aos processos midiatizados no Brasil e a análise de interações em curso em dispositivos midiáticos estruturados a partir das tecnologias chamadas de Web 2.0. O contexto empírico do caso aqui construído é o Observatório de Imprensa.

As questões de investigação são: em que medida as transformações tecnológicas do OI produzem instabilidade no dispositivo estrategicamente desenhado pela instituição (no caso, 
de crítica da mídia)? Procuramos responder a essa questão observando as transformações nas interações e semio-discursivas antes e depois das transformações da plataforma do OI - que passou, em 2011, a utilizar tecnologias digitais caracterizadas como Web 2.0. As inferências abrangem três níveis: primeiro, de uma categorização dos eventos observados; segundo, de reflexão sobre interpretações concorrentes; terceiro, sobre os limites metodológicos dessa análise e possíveis desdobramentos.

\subsection{Contexto teórico: a incerteza no modo de produção e formação midiatizada brasileira}

O estágio nos processos midiáticos atual é de ruptura com um longo período. Há uma superação dos dispositivos que deixam o receptor fora do processo de produção. O receptor ingressa no processo como produtor, e os produtores clássicos da "sociedade de massa" instituições midiáticas - assumem o papel de receptores midiáticos como condição de continuidade do lugar institucional que disputam na esfera da produção. A midiatização sofre um deslocamento histórico, em que a circulação inter-midiática passa a polarizar a produção social de sentido, correlata ao deslocamento de agentes e instituições não midiáticas ao lugar de produção ao lado das instituições midiáticas clássicas da "sociedade de massa".

As produções dos discursos contemporâneas, nesse modo de produção, não pertencem mais isoladamente às instituições não midiáticas (modelo clássico, que fundou a visão de Aristóteles sobre a comunicação); nem, às midiáticas (modelo da sociedade de massa); mas incorporam, transformadas, os discursos dos agentes sociais em rede que, nesse processo, operam para transformar os dispositivos em meios de busca da identidade e expressão de si (Flichy, 2010).

Nessa fase de ruptura de longo alcance, se coloca a possibilidade de construção e revelação de discursos potenciais (entendendo esses como denegados, reprimidos, mas não realizados). Há, é claro, dispositivos nesses modos de produção mais propícios a essas superações (por exemplo, o facebook e o blog mais do que o twitter ou o MSN). Mas há situações novas (exemplo: narrativas distribuídas em dispositivos móveis, em que o celular é utilizado para distribuição e, quem sabe, valorização/circulação de discursos).

Outra dimensão de ruptura é sua viabilidade como operação técnica conforme suas configurações tecnológicas. O que destacamos aqui é a emancipação do discurso de domínios 
específicos da técnica (literária, cinematográfica, documental, jornalística, etc.), com potencial retorno a todos os que, reunindo algumas competência e capitais, e seguindo os padrões técnicos articulados às tecnologias disponíveis, fazem a sua própria configuração dramática (rumo à consagração dos amadores, conforme Flychy, 2010).

Mas a midiatização não é um processo homogêneo, com validade universal. Não é aplicável a todos os territórios, regiões e espaços sociais. Sua configuração está delimitada por seu pressuposto: é necessário que os indivíduos se insiram como, potencialmente, sujeitos de seus discursos, o que implica na requisição de sociedades civis que tenham respondido às premissas da mercantilização da cultura, da política e da economia. Ou seja, a inserção dos receptores na esfera da produção, como dimensão central da circulação autonomizante, requer que os indivíduos sejam "livres" - mesmo que isso seja conforme os pressupostos da liberdade mercantil (formal), para que, aí, situem-se de diversas formas, seja como sujeitos à ou como sujeitos de.

É nesse sentido que falamos de formações sociais singulares. Uma formação social será potencialmente mais midiatizada conforme os diferentes níveis de autonomia formal dos indivíduos, mesmo que essa formalidade seja aparente, na medida em que subordinados às diversas determinações sociais e biológicas. A autonomia formal dos indivíduos se manifesta em produção de discursos próprios, requisito sócio-antropológico à inscrição dos mesmos em dispositivos midiáticos. Mas autonomia dos indivíduos deve ser contextualizada por mediações antropológicas, discursivas e tecno-tecnológicas.

\subsection{As mediações sócio-discursivas}

Recordando a proposição: o pré-requisito sócio-antropológico da midiatização é a mercantilização diversificada da sociedade (não só econômica, mas cultural, política, dos desejos, afetos, etc.). É nas brechas das diversas economias em circulação, que o individuo se coloca. Mas esse contexto não é homogêneo nas diversas formações midiatizadas. Umas das diferenças fundamentais se referem ao corte identificado por Lahire (2002) entre as práticas (esquemas de longo prazo identificáveis nas condutas) e as interações e usos (onde são visíveis os esquemas de curto prazo).

Por isso, a perspectiva de Lahire (2002) é interessante para pensar a força dos processos de interação e usos perante as práticas sociais incorporadas na formação social 
midiatizada no Brasil. A formação brasileira é próxima aos casos de "desvio e desajustamento" (Lahire, 2002) do mundo social. Destacamos algumas específicas:

a) Contradição com o até então incorporado _ diversidade histórica e cultural da formação Brasil, sem hegemonia definida. Ilustrações: não há projetos fortes de um Brasil purificado etnicamente; no campo religioso, a uma profunda transformação com a emergência do movimento neo-pentescostal.

b) Migrações internas remetendo a diversidade.

c) Desvios entre disposições e situações - os outros em ambientes de outros, etc. Ilustrações: os novos contextos produzidos pelas cotas nas Universidade Públicas; irritações no STF com Joaquim Barbosa; Lula na presidência.

d) Transformações históricas fortes - populismo, ditadura, democracia, novas configurações recentes, na economia e na política.

Nesta sociedade, singular, as perspectivas que analisam as práticas perdem valor perante aquelas que acentuam as mediações, as interações, ou, se quisermos, entre nós, a circulação. Essas situações acentuam a importância do presente sobre o passado, das interações relativamente aos contextos, dos usos em relação às práticas. Configura-se aí uma base no real (ontológica), que fortalece ângulos interacionistas na análise dos processos de comunicação no Brasil. Mas isso significa que temos, nessas situações, o indivíduo em processos de liberdade de escolha?

Mesmo que o espaço de liberdade seja restrito, é nessa perspectiva que pensamos o individuo: atravessado por diversas determinações, não resta, ao individual, senão elaborar suas próprias sínteses, não predominantemente lógicas, mas principalmente em discursos próprios, em interlocução com seus pares no presente, em interações. O inverso disso é a violência, física ou simbólica, como método de resolução do conflito social decorrente da diversidade de práticas em jogo nas interações. E, no ponto intermediário, os amálgamas discursivos (Charaudeau, 2009), os quais ainda não apresentam sintomas claros de resolução das questões que sugerem sobre a cultura. Nesse sentido, nossa inferência é de que a espécie está se colocando problemas para os quais ainda não encontrou soluções coletivas (ao 
contrário do que disse Marx, para quem a sociedade só se coloca problemas para os quais tem soluções).

\subsection{A unificação do mercado linguístico versus sentidos e discursos em disputa}

Em termos sócio-antropológicos, a unificação dessa diversidade tem uma base na formação econômica e política, caracterizada como "via prussiana" por Carlos Nelson Coutinho. A grande mediação que acentuamos na unificação da diversidade de práticas é a unificação do mercado linguístico. Essa unificação atravessa várias fazes, do período colonial à república, com acento nos períodos de regimes autoritários:

O Estado Português e, depois da independência, o Estado Brasileiro, tiveram por política, durante quase toda a história, impor o português como a única língua legítima, considerando-a "companheira do Império" (Fernão de Oliveira, na primeira gramática da língua portuguesa, em 15362[2]). A política linguíística do estado sempre foi a de reduzir o número de línguas, num processo de glotocídio (assassinato de línguas) através de deslocamento lingüístico, isto é, de sua substituição pela língua portuguesa3[3]. A história lingüística do Brasil poderia ser contada pela sequiência de políticas lingüísticas homogeinizadoras e repressivas e pelos resultados que alcançaram: somente na primeira metade deste século, segundo Darcy Ribeiro, 67 línguas indígenas desapareceram no Brasil - mais de uma por ano, portanto (Rodrigues, 1993:23). Das 1.078 línguas faladas no ano de 1500 ficamos com cerca de 170 no ano 2000, (somente $15 \%$ do total) e várias destas 170 encontram-se já moribundas, faladas por populações diminutas e com poucas chances de resistir ao avanço da língua dominante (Oliveira, 2009, página 2).

Esta mesma política foi adotada em relação à migração de africanos e, depois, de italianos, alemães, russos, poloneses, etc. no século XIX e XX. Mas é no século XIX e XX, especialmente junto às regiões de imigrações de japoneses, italianos e alemães, que o processo ganha novas marcas:

A campanha de nacionalização foi implementada durante o Estado Novo (1937-1945), atingindo todos os possíveis alienígenas — tanto nas áreas coloniais (consideradas as mais enquistadas e afastadas da sociedade brasileira) como nas cidades onde as organizações étnicas estavam mais visíveis. O primeiro ato de nacionalização atingiu o sistema de ensino em língua estrangeira: a nova legislação obrigou as chamadas "escolas 
estrangeiras" a modificar seus currículos e dispensar os professores "desnacionalizados"; as que não conseguiram (ou não quiseram) cumprir a lei foram fechadas. A partir de 1939, a intervenção direta recrudesceu e a exigência de "abrasileiramento" através da assimilação e caldeamento tornou-se impositiva - criando entraves para toda a organização comunitária étnica de diversos grupos imigrados. Assim, progressivamente, desapareceram as publicações em língua estrangeira, principalmente a imprensa étnica, e algumas sociedades recreativas, esportivas e culturais que não aceitaram as mudanças; foi proibido o uso de línguas estrangeiras em público, inclusive nas atividades religiosas; e a ação direta do Exército impôs normas de civismo, o uso da língua portuguesa e o recrutamento dos jovens para o serviço militar num contexto genuinamente brasileiro.

A participação do Brasil na guerra, a partir de 1942, acirrou as animosidades, pois a ação nacionalizadora se intensificou junto aos imigrantes (e descendentes) alemães, italianos e japoneses - transformados, também, em potenciais "inimigos da pátria". ...Prisões arbitrárias, policiamento ostensivo, humilhações públicas como castigo pelo uso de língua estrangeira, cerceamento de atividades produtivas, associações esportivas requisitadas para uso militar etc. marcaram o cotidiano tenso de algumas regiões onde a maioria da população se enquadrava na categoria dos alienígenas (SEYFERTH, Giralda, 1997, 96-97).

Nesse sentido, é interessante que pensar os processos autoritários não apenas decorrem da problemática das relações entre economia e política - como frisam as análises marxistas. Está evidente que os regimes autoritários no Brasil são parte das tentativas de hegemonias culturais pela via prussiana (desde cima, do Estado).

A unificação linguística, entretanto, não assegura a unidade de sentido (semiose, ascendente, descendente e circular) e discursiva (desde a construção de um imaginário compartilhado até as estratégias sociais unificadoras da ideia de nação, pelos caminhos de uma semiose descendente). Os processos discursivos, pelo contrário, mesmo com base na mesma língua, manifestam a diversidade de práticas, atualizadas nos processos de interações e usos. Nesse sentido, a ideia de polissemia, no caso de uma sociedade em permanente situação de crise de desajustamentos, deveria ser repensada.

Teoricamente, esse contexto está muito bem decifrado, por Bourdieu (1982). Nessa coletânea, afirma que as línguas derivam de codificações e imposições generalizadas que são requisitadas pela dominação de uma autoridade política. A existência dessa autoridade é uma necessidade para um mínimo de comunicação num espaço de produção econômica e dominação simbólica. A escola ocupa um lugar fundamental nesse processo de "socialização", que é sempre incompleto, pois que, inscrita nos processos de comunicação, a 
língua normatizada é transformada conforme as estratégias de apropriação, interpretação e uso de produtores e receptores.

Nossa formulação é de que essa dispersão de sentidos e discursos nos processos de comunicação produzidos com base nos códigos linguísticos compartilhados sofre fraturas simbólicas diversas em sociedades em permanente crise de desajustamento como o Brasil. As diversidades são filo-genéticas, psico-antropológicas e sociais. É dessa diversidade que emerge, paradoxalmente, a força e o valor das interações nos processos comunicacionais no Brasil, pois que se trata de encontrar soluções no aqui e agora (ser "criativo"), suspendendo as práticas de referência para que os possíveis sejam viabilizados. Nesse sentido, há indícios de que a problemática entre semiose ascendente e descendente, referência linguística e discurso é homólogo entre a formação midiatização no Brasil e na França. A diferença estaria mais na esfera dos dispositivos que regulam esses processos (relações entre oralidade, escrita, rádio, televisão, imprensa, também inscritas na cultura).

\subsection{As instituições e indivíduos em tentativas ${ }^{1}$}

Nesse contexto de diversidade de práticas, as interações e usos ganham peso maior relativo, ao mesmo tempo em que expõe a ausência de referências que conservem a ideia de sociedade. Os desajustes são permanentes (culturais, econômicos, políticos e sociológico).

Os esforços de conservação (estabelecendo referências em termos de práticas) requisitam um trabalho redobrado das instituições coletivas (a generalização das relações públicas de que fala Bernard Miège), ao mesmo em que a diversidade de práticas favorece a individualização das relações sociais. Regulados por dispositivos midiáticos, tais diferenças revelam ausência de grupos de consensos (ideologias). Emerge, nesse quadro, características de uma fragmentação pós-moderna sem ter passado pela realização dos desafios da modernidade.

Num espaço social marcado pelo valor das interações perante as práticas incorporadas, a força dos dispositivos aumenta em termos de regulações. Não se trata de regulações de Estado (centralizadas), nem das regulações da cultura (baseada nas práticas de conhecimento, reconhecimento, vinculo e conflito), mas da dispersão de formatos de regulações mediadas por comunicação midiatizada, conforme os públicos de produção-recepção-circulação.

\footnotetext{
${ }^{1}$ Utilizo, nesse intertitulo, um termo que é central na reflexão de José Luiz Braga (2010)
} 


\section{CONTEXTO EMPÍRICO: CARACTERIZAÇAO GERAL DO DISPOSITIVO}

Os dispositivos midiáticos são os regulares centrais das interações em conjunturas de liberdades políticas. Mas há uma diversidade de formas de regulação. São centrais nessas formas de regulação o lugar que ocupam os mediadores entre as produções discursivas dos receptores e a incorporação das mesmas aos conteúdos disponíveis aos consumidores finais. No formulário de postagem do Observatório de Imprensa (http://www.observatoriodaimprensa.com.br/), essa mediação é visível:

Este é um espaço de diálogo e troca de conhecimentos que estimula a diversidade e a pluralidade de idéias e de pontos de vista. Não serão publicados comentários com xingamentos e ofensas ou que incitem a intolerância ou o crime. Os comentários devem ser pertinentes ao tema da matéria e aos debates que naturalmente surgirem. Mensagens que não atendam a essas normas serão deletadas - e os comentaristas que habitualmente as transgredirem poderão ter interrompido seu acesso a este fórum.

ATENÇÃO: Será necessário validar a publicação do seu comentário clicando no link enviado em seguida ao endereço de e-mail que você informou. Só as mensagens autorizadas serão publicadas. Este procedimento será feito apenas uma vez para cada endereço de e-mail utilizado.

Essas condições gerais podem ser identificadas em outros dispositivos. Assim, dispositivos abertos aos mercados - como, por exemplo, de instituições jornalísticas funcionam com um mecanismo central que pode ser sintetizado assim: controle (chamados de mediadores) selecionando conteúdos/discursos em conformidade com as estratégias da instituição, porém abertos a tematizações diversas, relativas a um espaço simbólico heterogêneo, acompanhando tendências do fluxo de distribuição informacional conforme o mercado discursivo de interação. Essas estratégias de mercado visam reforçar a inscrição das interações nos processos de valorização estrategicamente delimitados.

O observatório de Imprensa, entretanto, tem uma estratégia de buscar terceiros para a conversação - incluindo as tentativas claras de unificação simbólica, mas também de construção de trocas simbólicas a partir da incerteza, de construção de discursos de poder entendidos como tentativas de regulação moral, legal e instrucional dos mercados discursivos. 
Essas modalidades não esgotam as possibilidades efetivas de interações discursivas, com incidências nos processos argumentativos e narrativos audio-scripto-visual, produzidas pelos polos de receptores e produtores. Além disso, as estratégias delineadas pelas instituições são esgarçadas, e reconfiguradas conforme os processos de circulação. Nesse processo, está inscrita a problemática das gramáticas de produção e de reconhecimento (, 2007), mas também o processo de conservação, reprodução e transformação de crenças e valores sociais.

\subsection{0 corpus: 0 antes e o depois de integração às "redes sociais"}

Como objeto empírico, adotamos o mesmo corpus de pesquisa - artigos e comentários no Observatório de Imprensa, pensados na perspectiva da midiatização (Garcia, 2012). Primeiramente, foram levantados e observados todos os artigos de janeiro a junho de 2011 que tratavam do tema "governo de Dilma Rousseff", somando 44 artigos neste período 2 . Desse total, foram analisados os três artigos que apresentaram maior número de comentários explícitos nos rodapés dos artigos. Sendo eles:

a) O artigo publicado no dia 4 de janeiro de 2011, sobre o discurso de posse da Presidente Dilma Rousseff e os comentários gerados no rodapé desse artigo;

b) O artigo publicado no dia 7 de junho de 2011, logo após a renovação do site OI e ampliação de recursos de distribuição de conteúdos, sobre a queda do Ministro-chefe da Casa Civil, Antonio Palocci, assim como os comentários dos internautas e as manifestações quantitativas nas redes sociais;

c) E o artigo COLLOR \& GLOBO: A História revisada, de Luciano Martins costa, publicado em 29 de novembro de 2011.

As três tabelas abaixo sintetizam os indicadores relativos a cada um dos artigos referidos:

\begin{tabular}{|l|l|c|}
\hline \multicolumn{2}{|c|}{ Características } & \multicolumn{1}{|c|}{ Indicadores } \\
\hline Título & $\begin{array}{l}\text { Dilma presidente- os primeiros } \\
\text { silêncios. }\end{array}$ & \\
\hline Seção & Jornal de Debates & \\
\hline Data publicação & $04 / 01 / 2011$ & \\
\hline
\end{tabular}

2 Janeiro/2011: 14 artigos; Fevereiro/2011: 9 artigos; Março/2011: 5 artigos; Abril/2011: 3 artigos; Maio/2011: 5 artigos; Junho/2011: 8 artigos. 


\begin{tabular}{|l|l|c|}
\hline Autor & Deonisio da Silva & Escritor \\
\hline Comentários & 110 \\
\hline \multicolumn{2}{|l|}{ Não havia integração às "redes sociais" } & - \\
\hline
\end{tabular}

Quadro 1: Indicadores sobre artigo 1.

Fonte: pesquisa empírica realizada por Adriana Garcia (Garcia, 2012).

\begin{tabular}{|l|l|c|}
\hline \multicolumn{2}{|c|}{ Características } & Indicadores \\
\hline Título & $\begin{array}{l}\text { Palocci e os 3 porquinhos: mídia } \\
\text { começou serena, vai acabar } \\
\text { enfurecida }\end{array}$ & \\
\hline Seção & Jornal de Debates & \\
\hline Data publicação & $07 / 06 / 2011$ & \\
\hline Autor & Alberto Dines & Jornalista \\
\hline Comentários & 64 \\
\hline Twitter & 51 \\
\hline Facebook & \\
\hline
\end{tabular}

Quadro 2 - Indicadores sobre artigo 2

Fonte: pesquisa empírica realizada por Adriana Garcia (Garcia, 2012).

\begin{tabular}{|l|l|c|}
\hline \multicolumn{2}{|c|}{ Características } & Indicadores \\
\hline Título & $\begin{array}{l}\text { Collor \& Globo: a história } \\
\text { revisada }\end{array}$ & \\
\hline Seção & Feitos e Desfeitas & \\
\hline Data publicação & $\begin{array}{l}\text { 29/11/2011(originalmente foi } \\
\text { veiculado no programa } \\
\text { radiofônico do OI de } \\
\text { 29/11/2011) }\end{array}$ & Jornalista \\
\hline Autor & Luciano Martins Costa & 9 \\
\hline Comentários & & 67 \\
\hline Twitter & \\
\hline Facebook & \\
\hline
\end{tabular}

Quadro 3: Indicadores sobre artigo 3.

Fonte: pesquisa empírica realizada por Adriana Garcia (Garcia, 2012).

O corpus atendeu ao objetivo de verificar como os interlocutores interagem em contextos tecnológicos distintos. A principal transformação tecnologica no OI foram categorizadas por Garcia (2011) como sendo categoria interdispositivos, quando as "redes sociais" online são utilizadas para que os leitores espalhem/distribuam os conteúdos de crítica do site para outros espaços virtuais. São canais regulares: You Tube; Twitter e Facebook. 
O Artigo 1: "Dilma Presidente: Os primeiros silêncios" "3 trata do primeiro discurso da presidente eleita, Dilma Rousseff, alegando controvérsias na fala dela. O texto está embasado em dois eixos argumentativos: o primeiro afirma que a preferência de Dilma em ser chamada de "presidenta" é ambígua e está relacionada ao desejo dela em ser considerada "muié do Lula" (sic) (Deonisio da Silva). O segundo eixo julga como controverso o discurso de Dilma ao dizer que "não guarda ressentimento ou rancor", pois, ela silenciou o reconhecimento dos "méritos de Itamar Franco e de FHC, que arrumaram o país que Sarney e Collor, aliados dela e de Lula, esculhambaram" (sic) (Deonisio da Silva). Um aspecto importante a ser destacado como indício é que a construção dessa crítica ocorre a partir de um acontecimento político e não de uma prática jornalística, ou seja, não parte de uma construção noticiosa sobre um acontecimento político, configurando-se como uma crítica política.

O Artigo 2: "Palocci e os 3 porquinhos: Mídia começou serena, vai acabar enfurecida"4 tratou de um fato ocorrido no início do mês de junho de 2011: a série de entrevistas exclusivas para grandes empresas de comunicação - Rede Globo e Folha de São Paulo - que o então Ministro da Casa Civil, Antonio Palocci, concedeu para defender-se de acusações sobre enriquecimento ilícito. Nesse mesmo dia, horas depois da postagem do artigo no OI, foi divulgado à população que Palocci deixaria o cargo público. A argumentação do articulista Alberto Dines desenvolve-se em três eixos: o primeiro foi afirmar que Palocci era protegido de Dilma. Durante todo o artigo, o autor utilizou recursos de linguagem metafóricos. Na cartola do artigo, a expressão: "Palocci e os três porquinhos", chama atenção não só pela relação que pode ser feita com a conhecida história infantil, mas pela construção de sentido relacionada ao $m e m e^{5}$ que a presidente Dilma ajudou a criar para os seus coordenadores de campanha presidencial, os petistas Antonio Palocci, Eduardo Dutra e José Eduardo Cardozo ${ }^{6}$. O segundo eixo do argumento de Alberto Dines foi que Palocci era protegido por parte da grande imprensa, porém, dessa vez o desfecho seria outro. O articulista

\footnotetext{
${ }^{3}$ Disponível em: http://www.observatoriodaimprensa.com.br/news/view/os-primeiros-silencios

4 Disponível em: http://www.observatoriodaimprensa.com.br/news/view/midia-comecou-serena-vai-acabarenfurecida

${ }^{5}$ No contexto da internet, "meme" é a transmissão de informação de um internauta para outro, em analogia à linguagem como vírus. Em outras palavras, é quando alguém cria e outros reproduzem em exponencial escala, atingindo um grande número de internautas, os quais não precisam necessariamente compactuar coma ideia/mensagem do meme.

${ }^{6}$ O termo "Os três porquinhos", utilizado como referência aos petistas Antonio Palocci, Eduardo Dutra e José Eduardo Cardozo, virou meme na internet. O termo ficou famoso em novembro de 2010, quando a então presidente eleita Dilma Rousseff brincou, em público, referindo-se ao trio de políticos responsável pela coordenação da sua campanha. Fonte: Revista Exame. Vídeo disponível em: http://www.youtube.com/watch?v=dg8bwlsalsq\&feature=player_embedded\#!
} 
sustentou a ideia de que Palocci conseguiu regalias da mídia em várias oportunidades e que "a corporação midiática uniu-se para preservá-lo" (Alberto Dines). No entanto, dessa vez, o insucesso das entrevistas exclusivas à Rede Globo e Folha de São Paulo, para se explicar ao Brasil sobre denúncias de enriquecimento ilícito, "dissolveram magicamente" a imagem de Palocci. O terceiro eixo do artigo encarregou-se de condenar a suposta cumplicidade do Procurador Geral da República em arquivar a investigação sobre Palocci. O articulista julgou que isso desgastou a imagem do ministro-chefe. Além disso, a imprensa que também desempenhou cumplicidade poderia "sair salpicada" por não saber "ser Quarto Poder". A solução sugerida por Alberto Dines a Palocci era que ele se demitisse do cargo.

Diferente do Artigo 1, essa crítica foi construída a partir de um julgamento sobre as práticas jornalísticas, ou seja, os modos de construção noticiosa da grande imprensa sobre o acontecimento político, configurando-se como uma crítica de mídia. O título do artigo já revelava a abordagem: "Mídia começou serena, vai acabar enfurecida". Mas, ao mesmo tempo, é crítica ao campo político. Ao todo, 16 internautas comentaram nos rodapés do artigo. A circulação da crítica permaneceu do dia da postagem, 07 de junho de 2011 , até o dia $1^{\circ}$ de julho de 2011, quando não foram mais postados comentários e nem acionados os interdispositivos das redes sociais. Naquele período, de acordo com o sistema de contagem do site OI, houve 64 compartilhamentos do artigo via Twitter e 51 via Facebook ${ }^{7}$.

O artigo "Collor \& Globo: A História revisada", de Luciano Martins Costa, foi publicado no OI no dia 29 de novembro de 2011, no site do OI, depois de ser veiculado o áudio no OI no Rádio. O texto trata da entrevista do ex-diretor da TV Globo, José Bonifácio de Oliveira Sobrinho, o Boni, ao canal pago Globo News (26 de novembro de 2011), revelando que houve manipulação no debate entre os presidenciáveis Luiz Inácio Lula da Silva e Fernando Collor de Mello, na eleição de $1989^{9}$. Na entrevista, Boni disse que foi procurado pela assessoria de Collor para que fosse montada uma imagem que favorecesse o apoio do "povo". Boni então aconselhou Collor a tirar a gravata, passar glicerina no rosto para parecer suado e colocar sobre a bancada do debate pastas vazias, para simular dossiês contra Lula. A entrevista concedida por Boni gerou várias abordagens na imprensa brasileira. $\mathrm{O}$ articulista Luciano Martins Costa adotou como referência a produção jornalística do Jornal

\footnotetext{
${ }^{7}$ A constatação desses números foi conferida em outubro de 2011, porém, em fevereiro de 2012, junto ao artigo o sistema de contagem de compartilhamento do site estava zerado, remetendo que não havia sido realizada nenhuma distribuição de artigos nas redes sociais on-line.

${ }^{8}$ Disponível em: http://www.observatoriodaimprensa.com.br/news/view/a_historia_revisada_1

${ }^{9}$ Entrevista disponível em: http://www.youtube.com/watch?v=vrpurekmjku\&feature=player_embedded\#!
} 
Folha de São Paulo, que já era um desdobramento da entrevista de Boni, informando que Collor havia negado que sua assessoria tivesse pedido ajuda ao então executivo da TV Globo para favorecer a sua imagem, mas afirmou que tinha contato direto com "o Doutor Roberto" Roberto Marinho, presidente da Rede Globo, na época. O artigo de Luciano Martins Costa aborda a versão do atual diretor da Central Globo de Jornalismo, Ali Kamel, que afirmou à reportagem da Folha que o então presidente da Globo, Roberto Marinho, orientou Boni a auxiliar o candidato para o debate, e que o episódio, se era factível no contexto histórico da época, hoje seria impossível na emissora. A opinião do articulista é que essa é uma evidência do histórico de que a Globo, ao longo da história, sempre favoreceu seus candidatos preferidos em suas produções televisivas em geral.

O Artigo 3 ficou em destaque no site na edição semanal nº 670 (Fig.31) e gerou nove comentários explícitos no rodapé, entre os dias 29 e 30 de novembro de 2011. Foram realizados, até o dia 18 de fevereiro de 2012, 67 compartilhamentos no Twitter e 45 no Facebook.

\section{INFERÊNCIAS SOBRE CORRELAÇÕES QUANTITATIVAS}

As inferências aqui apresentadas não são as mesmas da dissertação da co-autora, Adriana Garcia. Buscamos, com o mesmo corpus, novas percepções, questões e inferências. Essas inferências são limitadas aos casos em análise.

A primeira inferência relaciona tecnologia e interação. A observação de correlações entre dados específicos dos corpus 1 e 2 indica, num primeiro momento, que haveria uma redução dos comentários inversamente proporcional a elevação dos número de compartilhamentos em "redes sociais". Essa primeira evidência permite um tipo de inferência tecno-determinista: as tecnologias não só produzem um efeito de distribuição conforme as ferramentas específicas (facebook, twiter), como também, ao mesmo tempo, reduzem o valor da inscrição discursiva típicas de dispositivos anteriores (comentários).

Essa formulação, trivial, poderia, então, levar a subordinar as transformações discursivas e interacionais ao tecnológico. Nesse sentido, os formatos de equilíbrios das trocas seria uma derivada da inscrição em mecanismos tecnológicos reguladores de interações em dispositivos midiáticos. A ausência de espaço de expansão (nas "redes sociais") eleva as tensões no único espaço disponível (os comentários, no primeiro artigo). Ao contrário, 
quando há possibilidade de dispersão e distribuição em facebook e twiter (artigo dois e três) aumenta a possibilidade de equilíbrio e estabilidade, com a redução de usos no espaço de comentários. A tecnologia surge aí como ampliação do espaço semiótico possível, que, retroativamente, diminui a sobrecarga no espaço antes existente, menor.

A segunda inferência remete a problemática da agenda. Nos processos observados, o primeiro artigo refere-se ao tema política e os dois seguintes, ao tema relação dos jornais com a política. Essa relação permitira um tipo de inferência do tipo agenda-setting: o tema dos artigos postados define maior ou menor abertura em termos de comentários. Ou seja, o tema política, em si, produziria maior dispersão e proliferação de comentários. O tema relação mídia e política teria um poder de agendamento inferior.

O contexto dessas segundas inferências pode ser endógeno e exógeno. Endógeno, porque sendo o dispositivo Observatório de Imprensa dedicado ao tema "relação entre mídia e sociedade", há, nesta agenda, competências acumuladas, níveis de práticas compartilhadas, que produzem um senso já visitado e, por isso, o equilíbrio nas trocas logo é atingido. Os usos e interações estão já num nível maior de incorporação (em direção às práticas) Já o tema política é estranho ao dispositivo, e tenderia a produzir maior desequilíbrio, dispersão e proliferação de comentários. Exógeno, poderia ser estudado como o tema - a política, sendo ele da esfera pública, produz mais tensões e conflitos de posicionamentos difusos e distribuídos na sociedade. O dispositivo OI, nesse sentido, é pequeno para o exercício de um objeto que não lhe pertence explicitamente, fazendo-se aí usos que não estão estabilizados pelas técnicas do fazer jornalístico.

A terceira inferência se relaciona aos ofícios dos autores dos artigos. Alberto Dines e Luciano Martins Costa são jornalistas. Deonísio é escritor. Será que a função de escritor afeta a distribuição em comentários? Será que a função de especialista-jornalista produz um tipo de competência interacional regulatória das trocas em temas-objetos de sua jurisdição? E, inversamente, o escritor, ao não dominar o tema "crítica da mídia", e o discurso jornalístico, desencadeia uma proliferação e dispersão de comentários?

Portanto, temos três conjuntos de inferências sobre as trocas no dispositivo, considerando os três artigos em análise:

a) As interações são determinadas pelas tecnologias, no sentido de que essas produzem proliferação de enunciados em "redes sociais", esvaziando a importância e valor dos comentários, nos quais os argumentos são explicitados. $\mathrm{O}$ artigo 1, produzido sem conexão 
com as "redes sociais", resulta em maior número de comentários (mais de uma centena) do que os outros, os que tem conexão com as "redes sociais" (inferior a duas dezenas de comentários). Nesse sentido, a inferência é que as interações discursivas em dispositivos midiáticos estão reguladas pelas tecnologias.

b) As interações são configuradas conforme as agendas, no sentido de que a proliferação de enunciados, visível em comentários, está condicionada pela agenda-tema do artigo que dispara as interações. O artigo número 1 produz uma proliferação de (usos) comentários por ter saído dos "trilhos" - isso é, do tema crítica da mídia - ingressando na esfera da política em sua especificidade. Os outros dois estão direcionados à crítica à mídia, e, por isso, desencadeiam interações próximas ao equilíbrio (práticas incorporadas). A inferência é de que os usos e as interações discursivas são diferenciadas conforme a pertinência do tema acionado pelo mediador ao dispositivo em que estão inscritas.

c) Interações diferenciadas conforme o ofício do autor do artigo (jornalista ou escritor), no sentido de que a proliferação de enunciados é maior quando o mesmo é produzido pelo escritor. A inferência é de que as interações, nesse sentido, são reguladas pelas competências discursivas correlatas ao dispositivo onde os mediadores (no caso, jornalistas ou escritores) estão inscritos. O dispositivo é jornalístico; competência discursiva de um escritor seria, nesse sentido, estranha ao lugar de mediador da crítica da mídia, produzindo instabilidade expressa em usos e interações.

\subsection{Aproximando o foco: inferências sobre as disposições discursivas}

As inferências acima abstraem o que ocorre no nível das interações discursivas. A aproximação do foco permite, como veremos abaixo, perceber outras relações em jogo no dispositivo.

Os casos em análise estão bem situados: interações em que estão em jogo as relações entre o campo midiático e o político. Os três artigos estão inscritos nesta relação. A diferença está em que o primeiro tem como tema o campo político; e os outros dois, a relação do jornalismo e da mídia com o campo político.

Já apresentamos a primeira inferência relacionada a essa inscrição em agendas: as interações discursivas são diferenciadas conforme a pertinência do tema-agenda, acionado pelo mediador, ao dispositivo em que estão inscritas - campo político, no artigo um; relações 
entre campo midiático-jornalistico e campo político, nos artigos dois e três. Vamos nos aproximar agora vendo como isso ocorre em termos de interações discursivas.

Nesse sentido, a inferência é de que o tema-agenda dos três artigos desencadeia diversas disposições críticas não só convergindo com os artigos, mas também divergindo, fazendo críticas aos autores dos artigos, ao dispositivo Observatório de Imprensa e ao jornalismo em geral. A crítica dos receptores indica uma crítica que ultrapassa os limites das críticas sugeridas pelos autores/mediadores. Os receptores fazer uma crítica em que afirmam que é uma regra geral a subordinação da mídia ao campo político, que atinge jornalistas, inclusive o Observatório de Imprensa e o jornalismo em geral. Portanto, a crítica realizada no Observatório de Imprensa também é colocada em suspeição/suspensão.

A questão que nos atualiza é saber como isso ocorre. Primeiramente, vamos descrever processos. Depois, buscar inferências. O central é a percepção de que as interações discursivas se desenvolvem em ordens-desordens que podem ser bem caracterizadas como "amalgama discursivo" (Charaudeau, 2009). Chamamos "amalgama discursivo" ao processo em que a retórica persuasiva (visando a captação de audiência), nas interações acionadas pelos mediadores, se rege pela explanação de convicções pessoais e reafirmação e disputas de imagens de disposições dos interlocutores, dispositivos e campos em questão (buscando provar coerência dessas instâncias conforme as convicções).

Nesse tipo de configuração discursiva, fica fragilizado o exercício de explicação, descrição e apresentação objetiva do objeto em reflexão crítica. Em síntese, as interações se desenvolvem mais sobre a reafirmação das imagens construídas e a paixão pelas posições assumidas do que pelo exercício de argumentação, baseada em referências de objetividade e lógica. Esse núcleo de atividade discursiva, visível nas interações, é o ponto de articulação de ordens discursivas diversas (jogos de interlocução; narrativas) em que ocorre deslizamento temático, ou seja, deslizamentos em que os campo-temas originais se desdobram em mundos que são paralelos, irredutíveis a uma lógica passível de articulação (economia, política, cultura, instituições diversas). 


\subsection{Artigo 1}

No caso do artigo de Deonísio, os comentários dos receptores questionam o Observatório de Imprensa como o lugar do discurso de crítica da mídia, ao mesmo tempo em que disputam a legitimidade das posições do comentarista (Dionísio) e suas convicções:

Receptor. Enviado em: 05/01/2011 11:53:27. "Deixo registrado o meu apoio ao seu texto, prof. Deonisio (sic). É um alento saber que ainda há intelectuais dispostos a criticar métodos e posturas do grupo político que hoje domina o governo. Esse é o papel dos pensadores independentes: criticar os erros e falhas de qualquer governo. Infelizmente, isso tem sido raro no ambiente cultural brasileiro, dominado por militantes raivosos e amargurados que combatem qualquer sinal de crítica, tidas por eles como sabotagem e tentativa de golpe contra um governo progressista. Não deixe de se manifestar nesse observatório, mesmo este sendo 99\% vermelho. Um forte abraço".

Ou:

Receptor. Enviado em: 04/01/2011 13:50:36. Eu prometi a mim mesmo que nunca mais comentaria artigos aqui do OI, mas depois deste acima, fica difícil manter a promessa. (...) Sim, a história é caprichosa. Quanta gente se esquece do que escreveu, não é? Elogia um dia, desmerece no outro...Conhece quem escreveu este texto, Sr. "intelectual"? Só rindo mesmo...a memória de um "intelectual" é assim mesmo...risos. É por esta e por outras parecidas que muitos deixam de ler o observatório. Quanta arrogância e impertinência".

A crítica à posição do emissor (Dionísio) e suas convicções também servem de base à crítica à classe de jornalistas - que sempre estariam a serviço do jogo político:

Receptor. Enviado em: 04/01/2011 17:41:08. “Quem tá na chuva tem que usar guarda-chuva, se não, molha. Quê que é isso intelectual?!!! ... Seu texto foi bem simples e todo mundo entendeu. Como vivemos numa democracia, com liberdade de imprensa e de expressão, o povo se expressou. Jornalistas e intelectuais não gostam do contraditório?".

Outra crítica ao autor do artigo, Deonisio, portanto ao seu lugar de fala, como sendo comprometido com partido de oposição ao governo do PT, invalidando suas convicções: 
Receptor. Enviado em: 04/01/2011 12:10:51. (...) imagino que o missivista é dos que não gosta do cheiro do Brasil que ele chama de "profundo"....

Conclama seus pares a não abandonarem seus postos e a defenderem o seu príncipe FHC (Fernando Henrique Cardoso)".

O peso do lugar/posição no debate demonstra a fragilidade do processo argumentativo, em favor da afirmação de validade de posições-disposições, como centro de validade do valor de convicções, que desloca a problemática da crítica para embates narrativos sobre os indivíduos envolvidos no embate:

Deonisio da silva. Enviado em: 04/01/2011 18:28:14. “Ao sr. M. J., Sao Paulo-SP - Analista. Eu tenho 33 livros publicados, entre contos, romances e ensaios. Em diversas línguas. Se o sr. nunca soube de mim, que posso fazer? Também nunca soube do senhor! Respeito é bom e eu gosto. (...) Na VEJA escrevi sobre o mensalão. Escrevo uma coluna semanal na revista CARAS desde o primeiro número. É de etimologia. Eu acho que minha presença ali, como tanta gente qualificada já reconheceu, melhora a revista. Assim também acham seus editores! Há colunas sobre outros assuntos. O sr. tem qualificação para fazer reparo às páginas e colunas da Caras? Pois, publiqueos! Não desqualifique o saber alheio com o que o sr. ignora! Para discordar, não é preciso desqualificar aquele de quem se discorda (...)".

Receptor. Enviado em: 07/01/2011 21:33:42. "Sou graduado em economia e pós-graduado em analise de sistemas, falo inglês e espanhol....nos meus 50 anos já rodei boa parte do Brasil e algumas do mundo....de analista de sistemas passei a pequeno empresário e provavelmente tenho bens e renda superiores as suas....nasci em uma família paulistana que sabia dar valor a cultura e aos ensinamentos cristãos....minha esposa é formada em história com mais de 30 de estudos e pesquisas......tenho filho no direito e outro na economia, ambos da USP.....desde dezembro estão em férias nos EUA....e ainda este ano um deles embarca para ficar por um tempo na Europa.....entre nossos amigos temos professores, juízes, pastores, advogados, engenheiros, empresários, políticos, escritores e etc............"

Há, entretanto, sintomas de uma reflexividade sobre os limites de uma argumentação que degenera em processos centrados em posições e paixões mais do que em argumentação explicações, demonstrações e demonstrações:

Receptor. Enviado em: 07/01/2011 15:12:36. "A coisa até que começou bem. "Presidente" ou "Presidenta"?. Uns e outros trouxeram colaborações interessantes. Depois de certo momento, porém, a coisa degringolou e a vaca 
foi para o brejo com bezerro e tudo. Em vez da discussão centrada nos argumentos começou o "Sabe com quem você está falando?’Ou "como ousas, oh vil membro da plebe ignara, do alto da tua monumental ignorância, contestar o meu qualificado, nobre e titulado saber?". E aí tivemos a citação dos títulos, das qualificações e das obras publicadas... Se fosse um concurso de títulos não teríamos dificuldade em apontar o vencedor. Ninguém apresentou biografia tão brilhante. Mas em se tratando apenas de um debate creio que perdemos todos. Perdemos principalmente a oportunidade de um debate educado e civilizado".

\subsection{Artigo 2}

Essas formas de críticas do receptor, configuradas em amalgamas discursivos, articulados por uma retórica persuasiva, podem ser observadas também nos comentários ao segundo artigo, de Alberto Dines (que é um jornalista), em diversas dimensões.

$\mathrm{Na}$ crítica ao jornalista, se acentua que estaria agindo subordinado a interesses internos ao campo midiático. O receptor questiona as convicções de Dines, ironizando o seu pretenso lugar de imparcialidade:

Receptor. Enviado em: 08/06/2011 08:19:11. O Sr. Alberto Dines ao que parece, quer um emprego na Folha (...)"

A relação entre convicções (disposições) em debate e posições (lugares) é também explicitada pelo receptor a seguir:

Receptor: Enviado em: 07/06/2011 18:36:50. ...Eu não vou com a cara do Palocci, mas não sou burro de não perceber que tão comendo o governo Dilma pelas beiradas, oh! Chamar-me de otário, não, né? Já armaram o cerco de novo pra derrubar mais um governo? Que diabos de país é este em que a direita, quando não dá golpes usando militares ficar a tentar golpes o tempo inteiro usando seus ratos de redação?"

Mas nesse comentário acima, assim como no abaixo, há sintomas de um processo argumentativo, quando o receptor propõe um deslocamento do problema a ser criticado:

Receptor. Enviado em: 07/06/2011 16:31:55. Dines, nem morro de amores por Palocci, mas falar em Estado de Direito,em mais um episódio de acusação sem provas, exigência de condenação antecipada,clamor por julgamento político e também, quebra de sigilo,é meio forte. Um dia isso já foi chamado de perseguição política. Hoje chamamos de moralização e ética na política (...)". 


\subsection{Artigo 3}

A relação entre posições (perante o campo político), convicções e habitus jornalístico também é central em alguns comentários de receptores ao terceiro artigo (de Martins Costa, jornalista):

Receptor. Enviado em: 30/11/2011 16:36:16. "Querem vender uma idéia furada de que só a chamada imprensa alternativa (argh) ou de esquerda seria isenta, e também o que é pior que isso acontece no próprio Observatório da Imprensa, com alguns jornalistas que se comportam como paladinos da justiça, e, portanto perdem credibilidade na hora de criticar a imprensa, poderiam ao menos tentar disfarçar.

Neste terceiro artigo, se percebe também fragmentos de argumentação crítica, ao sugerir um deslocamento da problematização sugerida pelo jornalista:

Receptor. Enviado em: 30/11/2011 16:36:16. "Seria bom revisar também a história pelo outro lado. Na época a revista Imprensa publicou uma matéria de capa, intitulada Cai a máscara da isenção da imprensa brasileira, (...) divulgou-se que jornalistas petistas cobriam as matérias de entrevistas com Collor com broches do PT.

\section{CONSIDERAÇÕES}

As inferências finais partem do ponto de chegada, exposto acima: na análise dos comentários dos receptores, e interações com os articulistas do Observatório de Imprensa, observa-se uma fragilização dos processos argumentativos. Há poucos enunciados de problematização, explicação, descrição e reflexão lógica sobre os temas e fatos apresentados nos três artigos. O "debate" se desenvolve entre afirmações de auto-imagens e convicções subjetivas, produzindo interações com forte componente emocional (visível nas provocações e irritações inter-locutivas), típicas de uma crença pré-racional, articuladora de retóricas de persuasão. O amálgama discursivo (Charaudeau, 2009) se expressa numa argumentação esgarçada por outras ordens (persuasão, narrativas dramatizantes, jogos interlocutivos) e por deslizamentos temáticos (campos político, midiático, econômico e cultural).

Essa economia discursiva, pode-se inferir, é a aura do dispositivo. Formam o seu mercado, instável, sem dúvida, pela desconexão com os propósitos enunciados pelo 
Observatório de Imprensa ${ }^{10}$, mas sinergético na medida em que mobiliza, opera e incide sobre os amalgamas discursivos que compõem a cultura, incluindo a componente emocional, de desejo, de divisão dos embates entre adeptos do bem e do mal (como diz Charaudeau, 2009). A subsunção do discurso crítico-argumentativo ao amálgama nos leva a percepção de que o dispositivo Observatório de Imprensa perde sua aura de meio-mediação da crítica social ao jornalismo e aos meios, para se se inscrever em novas economias discursivas (nesse sentido, seria interessante buscar analogias e homologias com interações observáveis no Facebook, em torno de temas correlatos - crítica da política e da mídia na relação com a política).

É essa economia discursiva que articula, então, os três conjuntos de inferências sobre as trocas no dispositivo, considerando os três artigos em análise:

a) As tecnologias digitais possibilitam, com a inscrição do receptor na esfera da produção, a realização de amalgamas discursivos não manifestos sobre temas antes restritos a enunciação de especialistas. Quando em redes sociais, esses amálgamas se distribuem, são dispersivos, mas continuam proliferando conforme as lógicas da verdade do "bem" e do "mal", das afirmações de imagens/contra/imagens, de posicionamentos de convicções, mais do que de argumentação, explicação, descrição e problematização de um tema-objeto de debate. Entendemos que isso ocorre pela própria dispersão de competências (ou seja, os receptores não são especialistas no discurso específica de critica da mídia, mas em outras áreas, quando não simplesmente sejam não especialistas). A formação de amadores (Flichy, 2010) pode vir a ser uma mediação importante nesse processo.

b) O amalgama discursivo se "alimenta" especialmente de deslizamentos temáticos (seja quando um tema não é objeto explícito do dispositivo, ou quando a argumentação não é típica do dispositivo, como no artigo do Deonísio) e tem mais dificuldades de se alimentar quando o discurso do

\footnotetext{
${ }^{10}$ Este é um espaço de diálogo e troca de conhecimentos que estimula a diversidade e a pluralidade de idéias e de pontos de vista. Não serão publicados comentários com xingamentos e ofensas ou que incitem a intolerância ou o crime. Os comentários devem ser pertinentes ao tema da matéria e aos debates que naturalmente surgirem. Mensagens que não atendam a essas normas serão deletadas - e os comentaristas que habitualmente as transgredirem poderão ter interrompido seu acesso a este fórum.
} 
dispositivo está contido em seus contratos e formatos (artigos de Alberto Dines e Martins Costa).

c) Nesse sentido, a emergência e realização do amálgama discursivo em dispositivos dependem das competências dos comandatários (nos casos, os articulistas). Suas competências em regular o processo (com método e autoridade de ethos) podem direcionar as configurações do dispositivo, contrapondo, no caso, fragmentos de argumentação crítica que tencionam os amalgamas discursivos em configuração.

Quando configurados em amalgama discursivo, as críticas dos articulistas são também criticadas, produzindo discursos de crítica do dispositivo OI, de crítica da mídia. Ou seja, nos casos estudados, os discursos dos receptores, que passam a ocupar o lugar de produtores, acentuam que o OI, imerso no mesmo contexto que critica no jornalismo e nos meios, está impossibilitado de "criticar a mídia" em dispositivos midiáticos, na medida em que são também condicionados pelos mesmas restrições que criticam.

Seria isso uma tendência de uma matriz cultural onde a dispersão de sentido e discursos relativizaria qualquer tentativa de estabelecer referências compartilhadas para as práticas? Somente estudos que considerem outras formações (ou seja, outros países) poderiam revelar respostas sólidas para essa questão.

Porém, a fragmentação é um dos marcos das teorias pós-modernas. Em nossa formulação acentuamos que tal fragmentação é inerente a midiatização. Primeiro, porque o processo de circulação integra dialéticas decorrentes das tensões entre diversos níveis simultâneos e paralelos de circulação: entre as instituições midiáticas; entre as instituições midiáticas e não midiáticas; entre os indivíduos e as instituições midiáticas e não midiáticas. Essa continuidade e tensão afeta a esfera de cultura, integrando o próprio se fazer em e o fazer dos dispositivos, sem a isso se reduzir. A inscrição dos indivíduos nos processos de produção, faz emergir configurações discursivas marcadas pelo desejo, pela percepção do mundo entre o "bem” e o "mal”, pela afirmação de auto-imagens e de convicções pessoais.

Em decorrência, a midiatização transforma as formas de legitimação das instituições, na medida em que essas estão constituídas por discursos, incluindo os produzidos na inscrição dos receptores na produção discursiva dos dispositivos. As instituições - no caso, o 
Observatório de Imprensa - são transformadas pelos discursos dos indivíduos (receptores transformados em produtores).

Terceiro, nesse âmbito de estudos, é válido considerar a proposição de que as tentativas de controle do discurso continuam, mas está tensionado pela construção social de novos discursos em dispositivos que são dispersos e diversos. Emergem, nos dispositivos, a diversidade semiótica e estratégica que a unificação linguística tentou unificar, reprimir e denegar. Tudo é tocado pela dispersão recusada, inclusive quando o objeto é a crítica da mídia. Mais do que a verdade, o debate no Observatório visa a verossimilhança, o fazer crer, com distinções morais sobre as tensões em curso. Essa inferência necessita, para ser validade, de estudos comparativos entre diversas formações sociais midiatizadas.

\section{REFERÊNCIAS}

BOURDIEU, Pierre. Ce que parler veut dire. L'économie des échanges linguistiques. Fayard, 1982.

BOUTAUD, Jean-Jacques y VERÓN, Eliseo, Sémiotique ouverte. Itinéraires sémiotiques en communication, Paris, Lavoisier, Hermès Science, 2007.

BRAGA, José Luiz. Nem rara, nem ausente - tentativa. In: Matrizes, v. 4, n. 1 (2010). disponível em http://www.matrizes.usp.br/index.php/matrizes/article/view/179.

CHARAUDEAU, Patrick. LA ARGUMENTACIÓN PERSUASIVA. EL EJEMPLO DEL DISCURSO POLITICO, in Shiro M. \& alii, Haciendo discurso. Homenaje a Adriana Bolívar, Facultad de Humanidades y Educación, Universidad Central de Venezuela, Caracas, 2009 ,

FERREIRA, Jairo; FOLQUENING, V. . O individuo e o ator nas brechas da midiatização: contrabandos em espaços conjuminados. Diálogos de la Comunicación (En línea), v. 1, p. 1-21, 2012.

FLICHY, Patrice. Le sacre de l'amateur. Sociologie des passions ordinaires à l'ere numérique. Paris: Seuil, 2010.

GARCIA, Adriana Domingues. Irritações no espaço do quinto poder: ritos e fragmentos de construção da crítica de mídia no observatório da imprensa. Dissertação de Mestrado: PPGCCC- UNISINOS. Orientação: prof. Dr. Jairo Ferreira. São Leopoldo: Unisinos, 2012.

OLIVEIRA, Gilvan Müller. Brasileiro fala português: Monolingüismo e Preconceito Lingüístico. In: Revista Linguasagem. Número 11, 2009. Disponível em: www.letras.ufscar.br/linguasagem. Outubro de 2012 


\section{SEYFERTH, Giralda. A ASSIMILAÇÃO DOS IMIGRANTES COMO QUESTÃO}

NACIONAL. In: MANA 3(1):95-131, 1997.

Original recebido em: 19/01/2013

Aceito para publicação em: Novembro de 2013

Jairo Ferreira

Professor Titular do Programa de Pós-Graduação em Ciências da Comunicação da UNISINOS. Pos doutor em comunicação pela UNR (Argentina). Formado em Jornalismo (UFRGS, 1982) e Ciências Econômicas (UFRGS, 1992), é mestre em Sociologia (UFRGS, 1997) e doutor em Informática na Educação (UFRGS, 2002).

Adriana Domingues

Mestre em Ciências da Comunicação pela Universidade do Vale do Rio dos Sinos (Unisinos), na linha de pesquisa Midiatização e Processos Sociais, com titulação em 2012. Jornalista graduada pelo Centro Universitário Franciscano (Unifra), com graduação em 2008. 